\title{
O valor da dimensão extática da Igreja: estudo teológico-pastoral sobre a Renovação Carismática Católica no Brasil
}

Orientador: Abimar Oliveira de Moraes

Mestranda: Maria de Fátima de C. F. Barbosa

Área de Concentração: Teologia Sistemático-Pastoral

Linha de Pesquisa: Fé e Cultura

O objetivo dessa dissertação é pesquisar o valor da dimensão extática da Igreja. Fazendo um estudo teológico-pastoral sobre a Renovação Carismática Católica no Brasil. Com isso, começaremos a nossa pesquisa apresentando o desejo de Deus em se comunicar com o ser humano e como consequência este tem a necessidade de acolhê-Lo e se comunicar com Ele. Esta ânsia de comunicação, manifesta-se no arco da história das religiões de diversas formas, uma delas é o êxtase. Investigaremos, então, a função que o êxtase tem na experiência religiosa cristã primitiva. Faremos um percurso histórico a respeito do êxtase no antigo Israel, como também na experiência religiosa de outros povos que tiveram contato com Israel. Isto para podermos compreender a experiência extática veterotestamentária como também neotestamentária. Mostraremos a dimensão extática na Igreja dos Atos do Apóstolos e na Igreja de Corinto. Veremos que por causa desta dimensão extática, os carismas transbordavam e milagres e prodígios aconteciam abundantemente. Com isso, a cada dia mais e mais pessoas se juntavam a eles, pois eram Igrejas inclusivas onde ninguém passava necessidades. Em seguida, apresentaremos como ao longo dos tempos, devido as dificuldades enfrentadas, surgi a necessidade de sistematizar a Igreja. Provocando o enfraquecimento da sua dimensão extática, dando preferência a defender a fé pela razão. A doutrina passa a ser racional e o kerigma perde seu lugar para a filosofia moral, acontecendo o declínio da Igreja extática. Contudo, o Espírito Santo sopra, mais uma vez, sobre a 
Igreja e o Concílio Ecumênico Vaticano II é convocado. Há neste momento da história, uma reviravolta na Igreja e o retorno dos carismas, havendo assim o reavivamento da Igreja extática, dando início a Renovação Carismática Católica. Em seguida, mostraremos as críticas e controvérsias que a Renovação Carismática Católica teve que enfrentar causando assim a necessidade de se sistematizar e hierarquizar. Finalizaremos a nossa pesquisa apresentando os riscos e as possibilidades pastorais, atuais, para a dimensão extática da Igreja. Mostraremos que apesar de estarmos vivendo uma transição epocal, a proposta cristã permanece a mesma e por essa razão é preciso recuperarmos o projeto de Jesus Cristo e a dimensão extática de Sua Igreja. Uma vez que a nossa intenção de mostrar que o êxtase é uma legítima expressão dentro de uma estrutura religiosa.

Palavras-chave: Espírito Santo. Êxtase. Carismas. 